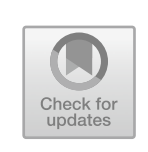

\title{
Restructuring Banks and Borrowers
}

\begin{abstract}
The systemic banking crisis subsided by March 1999, but it took five more painful years before the Japanese banking system recovered full health. This chapter reviews the process to restructure banks and borrowers and the impacts the process had on the labor force. It then tries to estimate the costs borne by corporates, banks, and taxpayers and explore what would have been the consequence if the immediate clean-up option had been chosen in 1992 .
\end{abstract}

Keywords Bad loans · Bank resolution - Corporate restructuring · Debt overhang · Unviable firms · Japanese employment $\cdot$ Resolution costs

By the end of March 1999, major banks had been recapitalized, and the safety net had been much strengthened. Bad loans were better provisioned against, and the regulator was revamped. With these, the systemic meltdown was averted, but the Japanese banking system had a long way to go before recovering its full health.

Figure 6.1 describes the key elements of the complications which were at work. Even after their decade-long decline, the asset prices did not stabilize and continued to impair the balance sheets of real estate developers and construction firms. In addition, the recession in the late 1990s made manufacturers and retailers run losses. By the turn of the

(C) The Author(s) 2021

R. Himino, The Japanese Banking Crisis, https://doi.org/10.1007/978-981-15-9598-1_6 


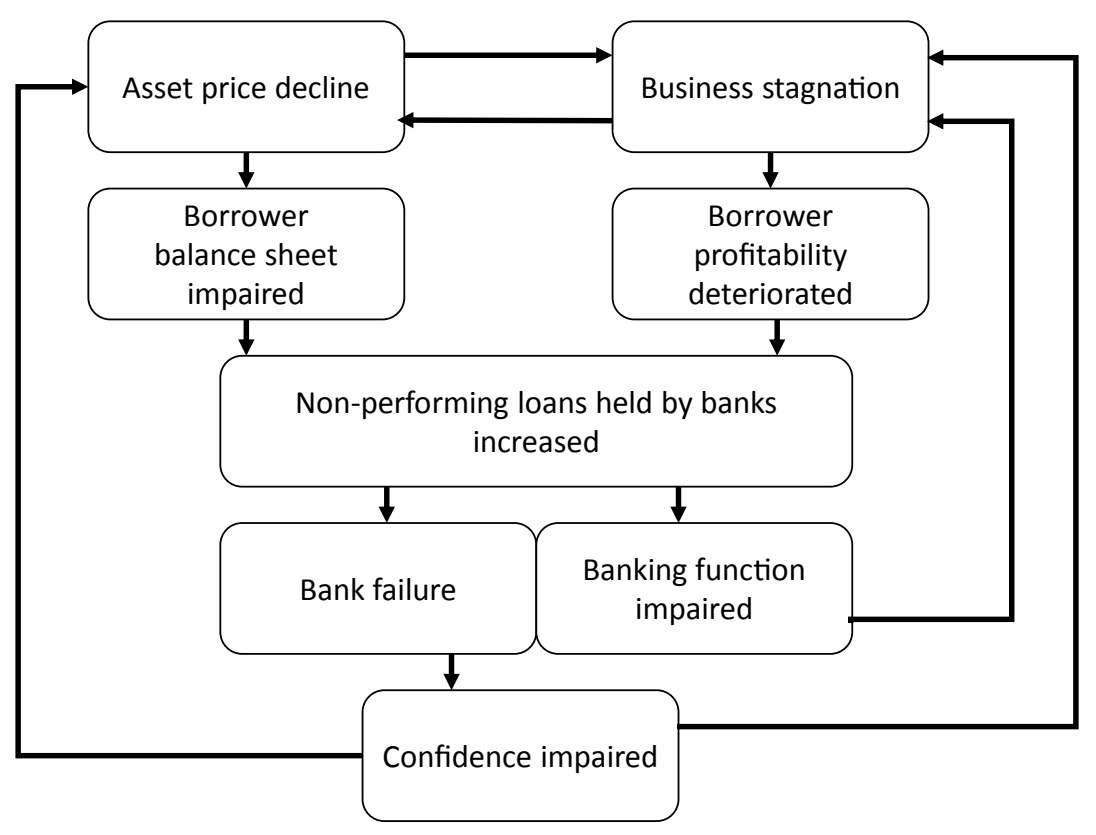

Fig. 6.1 Persistent vicious cycle (Source Author's illustration)

millennium, bad loans were mushrooming through both i) the traditional channel of borrower balance sheet impairment due to asset price falls and ii) the new channel of borrower profitability deterioration due to economic stagnation.

Every year, banks declared that they thoroughly looked at bad loans and disclosed them all, but they had to report much more in the following year. Market participants naturally suspected that regulators and bankers were hiding more problems.

Banks loaded with bad loans did not have much capacity to take additional risks. Bankers were busy dealing with existing borrowers with difficulties. Lending to new promising borrowers was clogged, prolonging stagnation. Borrowers were scared by the credit crunch in 1998 and had become cautious in making new investments.

Increased credit costs made banks fail, and big black headlines reporting new bank failures impaired public confidence in bankers and regulators, even though depositors were fully protected by the new safety 
nets. These developments in turn further pushed down asset prices and business activities.

Initially, many hoped that, if the asset prices stop declining and economic activities pick up, the vicious cycle would be reversed. Despite the enormous fiscal and monetary stimulus, however, the reversal had not happened even after a decade.

By summer 1998, it was widely recognized that cleaning up of bank and borrower balance sheets were needed to sever the vicious cycle and reactivate the economy. The cleaning up, however, was never easy. The JFSA tightened the standards, set new targets, repeated intensive on-site inspections, improved the mechanisms for borrower restructuring, and resolved numerous banks. But it took five more painful years to finally clean up the problem.

\section{Resolving BAD LoANS}

From 1998 to 2003, the JFSA $^{1}$ conducted three waves of on-site inspections to expose bad loans held by banks and to urge their early resolution.

The first wave of inspections was carried out from July 1998 to May 1999. The JFSA, in cooperation with regional finance bureaus of the Ministry of Finance and the Bank of Japan, conducted a Focused Inspection of loan books of all the 143 banks. Inspectors identified more bad loans than bankers did, and banks recognized a record credit loss for the fiscal year 1998. In the second quarter of 1999, 31 banks, shinkin banks, and credit cooperatives were resolved.

After the Focused Inspection, the scope of the review was expanded from asset quality to banks' internal processes including governance, compliance, and risk management. The Inspection Manual published in July 1999 incorporated a comprehensive checklist covering all such areas and guided the review. The number of the inspectors at the JFSA headquarters grew from 164 in March 1999 to 319 in March 2001 and those at the local offices grew from 456 to 567 during the same period.

The amount of bad loans, however, continued to increase even after the Focused Inspection. To put an end to the problem, the economic policy package published by the government in April 2001 requested banks to remove existing bad loans from their balance sheets within two years and new bad loans within three years ("2-year and 3-year rule"). Major banks were requested to disclose the progress and the JFSA was to monitor it. 
On the other hand, the short economic remission came to an end by September 2001. The GDP growth rate of the second quarter of 2001, published in September, turned negative. Nikkei Stock Price Index, which had been above 20,000 yen in March 2000, fell below 10,000 yen.

Confidence in the banking system was particularly impaired when a large supermarket group failed in September 2001. Bonds issued by the group had traded much below par, but banks had not classified loans to the group as doubtful. This incident strengthened market participants' suspicion that banks hided large amount of doubtful loans.

Responding to this, in the economic policy package in October 2001, the government declared that the bad loan problem shall be rectified within three years and announced that the JFSA would conduct a Special Inspection that focused on loans to large borrowers on which the capital market was signaling doubts.

This second wave of asset quality review was conducted between October 2001 and April 2002. In ordinary inspections, inspectors review bankers' assessments of the loan book after the annual financial statements are published. In this case, inspectors discussed with major banks how their large borrowers should be classified and provisioned concurrently with the process to produce the financial statements for the fiscal year 2001, which ended in March 2002. While the Special Inspection went on, 45 banks, shinkin banks, and credit cooperatives were resolved.

Gomi (2012), who was the director general of the JFSA's Inspection Bureau, recounts that he felt clear changes in bankers' mindsets by the end of 2001. One former inspector recalls that, when he did the Focused Inspection in 1998, major banks did not allocate quality human resource to the task of bad loan resolution, but that they started to treat the task as top priority around the time of the 2001 Special Inspection.

As shown in Fig. 6.2, both the disclosed amount of bad loans and the credit losses recognized by banks jumped up in March 2002. Further, the JFSA in April 2002 requested major banks to eliminate $50 \%$ of doubtful loans from their balance sheet within a year from the time classified as doubtful and $80 \%$ within two years (" $50 \%$ and $80 \%$ rule"). Combined with the "2-year and 3-year rule," the outstanding amount of bad loans should start to decline.

But the prime minister could not wait to see if these policies would work as envisaged. He replaced the minister for financial services in September 2002. The new minister, Takenaka Heizo, openly denied the approach adopted by his predecessor, Yanagisawa Hakuo, who directed 


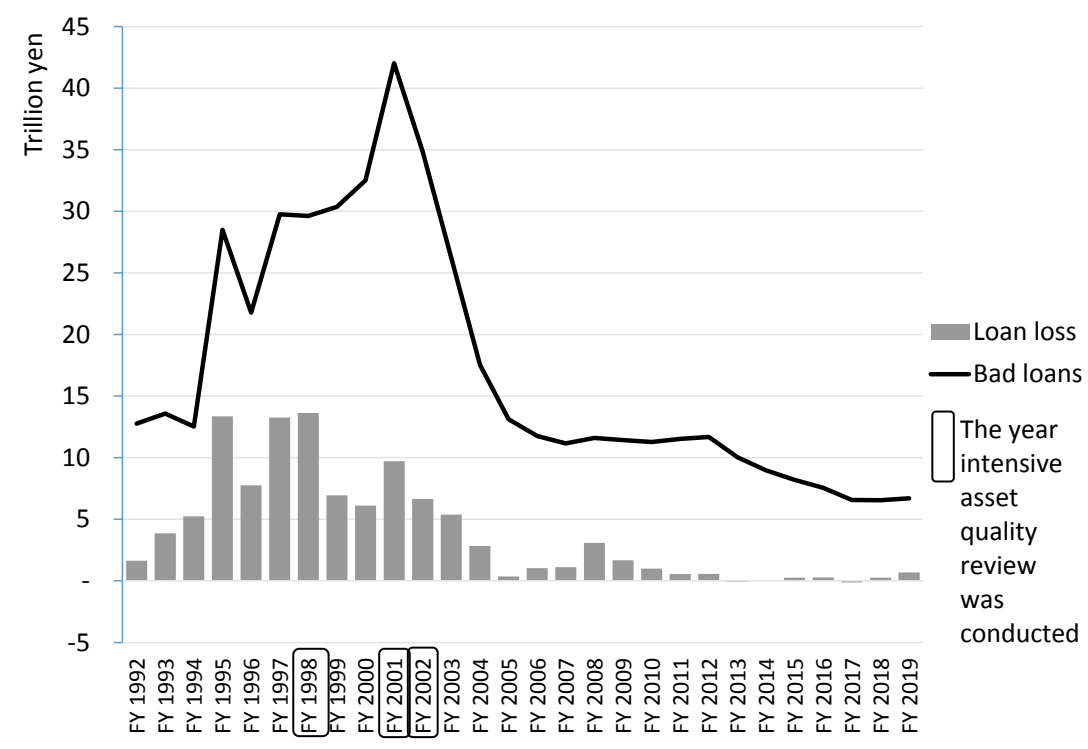

Fig. 6.2 Bad loans held by banks and loan losses incurred (Source Financial Services Agency, Disclosures according to the Financial Revitalization Act made for the accounting year ending in March 2020 (Reiwa 2 nen 3 gatsu ki ni okeru Kinyuu Saisei Hou kaiji saiken no joukyou tou), August 2020)

the Focused Inspection in 1998 and the Special Inspection in 2001. Responding to the criticism that his policy would lead to a hard-landing rather than a soft-landing, Takenaka (2008) argued "the policies taken so far have been 'never-landing' (i.e. never arriving at a solution), and those would lead in the long run to a 'crush landing' for the economy." In his view, the JFSA "was paralyzed by a sort of functional failure" and the JFSA bureaucrats "were prisoners of the idea of bureaucratic infallibility (the public demonstration of an attitude implying that all the policies adopted so far have been impeccable)."

His confrontation with big banks was highly publicized. Takenaka (2008) recounts about the press conference the CEOs of big banks jointly held in October: "When my staff members and I watched the proceedings of the press conference, we were struck with the clear realization that we could 'win' this. The players who had created the non-performing loans in the first place, and who were now causing so much trouble for 
the Japanese people, were now seen in a position opposing the reforms. Moreover, the sight of the bank presidents grouped together at the press conference like a bunch of incompetents, fully exposing buddy-buddy group consciousness left over from the days of the old convoy system, was a graphic indication of the lack of governance at the current banks, as well as their lack of strategy. The public would never support such banks - I was convinced of that."

One month after taking office, Minister Takenaka and his team published a new policy package. The package set the goal of cutting major banks' bad loan ratio by half by March 2005. To attain the goal, the package announced that (i) the discount cash flow approach shall be used in provisioning against doubtful loans, (ii) inspectors shall require major banks to adopt consistent classifications of large problem borrowers, and (iii) the JFSA shall disclose the aggregate amount of gaps between bankers' own assessment and inspectors' review and issue administrative sanctions on banks if the gap persists unreasonably. With these sticks in hands, the JFSA inspectors conducted another round of Special Inspection from January to April 2003.

While waiting for the outcome of the Special Inspection, the whole Japanese economy was in suspense. As the $50-80 \%$ rule introduced by the former minister Yanagisawa was still alive, majority of the borrowers newly classified as doubtful had to be restructured or resolved within a year or two. Speculations on imminent bankruptcies of large zombie firms were hazarded, and, on April 28, 2003, the Nikkei Stock Price Index hit the record low of 7604 yen, the level almost half of the bottom seen during the 1998 crisis. Some also speculated that some of the major banks may turn insolvent. The fear of another systemic crisis prevailed.

However, banks' annual reports published by the end of May 2003 showed that, despite the enhanced scrutiny, the amount of bad loans declined. The amount of credit losses, measured using the discount cash flow approach, was also lower. In other words, this round of Special Inspection underscored that the preceding round had already properly identified bad loans and loan losses. At the same time, the new minister's highly confrontational discourse worked to convince the market that no forbearance was exercised and gave strong credibility to this outcome. The capital adequacy of one major bank, Resona Bank, dipped below the regulatory minimum, but, as described below, the government gave a precautionary capital injection, avoiding wipe-off of the shareholders' rights and dissipating the fear of another systemic crisis. 
Stock prices were reversed. An economic boom started in the United States gave the Japanese economy a long-awaited stimulus. The real GDP, which was almost flat in 2001 and 2002, resumed growth at an annual rate of around $2 \%$. The bad loan ratio of major banks continued to decline from 8.4\% in March 2002 and reached 2.9\% in March 2005, overachieving the goal of halving, and stayed at the low level since then. In FY 2005, the Japanese banks incurred almost no credit losses in aggregate. The six large city commercial land price index, which had continued to decline for 15 years, started to pick up in March 2005. The vicious cycle described in Fig. 6.1 was reversed, and finally came the long-awaited reverse Minsky moment.

The initiative taken by Minister Takenaka has been among the most controversial of the financial sector policies adopted in Japan. In the view of Gomi (2012), who served both Yanagisawa and Takenaka at the JFSA, "The directions pursued by the two ministers were by no means contradictory. The approach adopted by Minister Yanagisawa in fact did not allow banks to take time or to proceed on their own speed." On the other hand, Takemori (2009) argues, "It was, after all, the matter of confidence. . . . It was absolutely necessary for someone to demonstrate that the problem was finally and irrevocably resolved, using means everyone could clearly understand." When the US authorities conducted stress tests in early 2009 and put an end to the crisis of confidence, some commentators in Japan compared this with the shock treatment administered in Japan six years before.

\section{RESOLVING BANKS}

During this financial cycle, 181 banks, shinkin banks, and credit cooperatives were resolved. Of which, 63 were resolved before the full sets of resolution tools were installed in October 1998. The authority had to painstakingly craft and tailor ways to protect depositors for each individual case.

At the time of the introduction of the full safety net, the plan was to clean up non-viable banks by March 2001 and to reinstall a ceiling on deposit protection in April. The ruling parties considered the reinstallment premature and postponed it by one year, and the JFSA largely completed the clean-up job by the new deadline of March 2002, resolving 117 institutions. 
Minister Yanagisawa directed the resolution of 99 institutions. During the last quarter of 2001, the frequency of failures reached three in one week. Each and every resolution was accompanied by strong political and social repercussions and technical and operational challenges, but no systemic disruptions or runs occurred.

His successor, Minister Takenaka, had to handle two high profile cases, one of a major nationwide bank and the other of a key regional bank. The capital adequacy of the former, Resona Bank, dipped below the regulatory minimum, and the government injected 2 trillion yen of capital and replaced the management in May 2003. The latter, Ashikaga Bank, was found to be of negative net worth. The government nationalized it in November 2003 and nominated a new CEO. The systemic risk clauses of the Deposit Insurance Law (the last two columns of Table 5.1) were applied to these cases, as Resona was judged systemic to the national economy, and Ashikaga, to the regional economy. There has been no bank failure since then, except for one idiosyncratic case.

\section{RESTRUCTURING BORROWERS}

Bad loans for banks are excess debts for distressed borrowers. Banks have four options: (i) to continue to lend and provision against the loans, (ii) to work with the borrowers and help them resurrect by restructuring their business models and balance sheets, (iii) to trigger liquidation procedures and receive proceeds, or (iv) to sell loans to new investors. The way banks resolve bad loans determine the fates of the distressed borrowers, their employees, suppliers, customers, and the national and regional economy.

During the in-between years, the Japanese banks largely chose the first option to provision against potential losses without addressing borrowers and wait till the borrowers fail or recover. The drawback of this approach had long been known: It can harm banks as banks tend to incur further losses year after year if the asset prices continue to decline or the borrowers continue to run losses. Bankers will be occupied with monitoring distressed borrowers and may not be able to focus on more promising borrowers.

In addition, perhaps more importantly, such an approach can also damage borrowers and the economy through two channels: debt overhang and delayed exit of unviable firms. 
First, debt overhang. According to Myers (1977), the book value of a company refers to assets already in place, whereas a significant part of firms' market values comes from the present value of future growth opportunities, which can be realized only if the company makes further discretionary investments. He showed that the existence of corporate debt can reduce the latter by weakening the corporation's incentive to undertake good future investments.

Suppose Company A had a factory and engineers which can adapt to future changes in technology and demands, and a major part of the company's value consisted of the growth opportunity, not of assets in place. Also suppose that, in the late 1980s, the company invested in a commercial real estate using money borrowed from banks, and by mid1990s, the company was with much bigger debts than the value of its assets in place. Banks hesitated to lend more to finance new investments, frustrating the growth opportunity and impairing the core of the corporate value. In the early 2000 s, the main bank kept large bad loans to the company, and the company had the factory, which was already obsolete, and the commercial real estate, whose market value was one tenth of the acquisition price, on the asset side of its balance sheet.

But what if the banks and the company could work together to eliminate this debt overhang by dividing the company into two, one taking over engineers with the factory on the asset side and some debts and some equity converted from debts on the liability side, and the other with the commercial real estate on the asset side and the large debts on the liability side? The latter has to be liquidated and the bank will surely incur losses, but both the company and the bank can avoid losing the value of the growth opportunity.

Second, delayed exit of unviable firms. Even if a company is currently with negative net worth or the current cashflow is insufficient to cover market rate interest payments, it still may be viable if it has a sound business model. By surviving a temporary adverse economic condition, by restructuring debts, or by shifting its business lines, it could be turned around. But firms are unviable if they lack sustainable business plans. ${ }^{2}$

Suppose Company B, which dominated the global market, invested in a big factory in the late 1980s, financing it by loans extended by banks. Competition with manufacturers based in other Asian economies intensified in the 1990s, and the company sold the products at prices which barely covered the variable costs but were totally inadequate to cover the fixed costs. It ran losses every year and could not embark on efforts to 
rebuild its competitiveness, but the bank, rather than to recognize a big loss writing off the whole loan, continued to lend and kept this unviable firm alive.

If the banks and the company could work together to wind down the company in an orderly manner, perhaps the banks could limit the ultimate size of the loan losses. Precious engineers, skilled workers, and any competent managers could be freed up from inefficient use and mobilized to build a new business model. New entrants may bring in animal spirits and new ideas and technology. The productivity of the Japanese economy could be enhanced.

In both cases, the second scenario looks better, but to make right choices, one needs to distinguish promising losers from unviable firms. Misdiagnosis could turn worse than wait and see approach: If we wind down the former, the valuable seeds of growth are prematurely killed. If we restructure the debts of the latter, we will be proactively delaying the exit of unviable firms.

During the golden age of what Aoki and Patrick (1995) called the Japanese main bank system, it was one of the key function of the main bank to make such judgments and administer restructuring or orderly winding down. There were many legendary cases in the Japanese economic history: Teikoku Bank saved Toyota in 1949, the Industrial Bank of Japan reconstructed Nissan Motor Co. and Nissan Chemicals in the 1950s and 60s, and Sumitomo Bank restructured Mazda in the 1970s and resurrected Asahi Beer in the 1980s. Without main banks, we would not see Lexus or Super Dry, much-loved national beer, today.

The task performed by main banks during the period of rapid economic growth, however, was much easier than the task to be performed in the post-bubble era. Previously most major companies had big growth opportunities, but, after the collapse of the bubbles, economy stagnated, and many borrowers' growth opportunities turned questionable. Before the financial deregulations in the 1980s, a main bank had close ties with borrowers, which helped monitoring them, but the relationship had been much weakened since then. Banks' high profitability and accumulated latent gains in the equity portfolio helped them withstand temporary costs to be incurred in restructuring borrowers, but such financial clout was almost depleted during the 1990s. Although main banks continued to perform central roles in addressing many of the distressed borrowers, a mechanism which can complement main banks' 
role had to be created to implement effective corporate resolution and restructuring.

Indeed, such need had long been recognized. Chicken and egg problems, however, persisted: Banks did not sell bad loans as there were no secondary market, and the market did not develop as banks did not sell. Corporate restructuring professionals could not accumulate experience as there were only limited cases, and corporate restructuring did not proceed as there were few experienced experts. There also was a first mover problem: When multiple banks lend to a borrower, the bank which initiated restructuring tended to bear bigger burden. Moreover, the existing corporate resolution processes focused on liquidation, were rigid, and took many years to complete.

Enormous efforts had been taken to create private and public agents who can administer restructuring. New agents born during the post-crisis phase include the following:

- Loan servicers: Amid the crisis in 1998, interested congressmen submitted a bill to make it possible to establish companies specialized in the business to collect loans for financial institutions or to purchase loans from them, the business which had been allowed only for lawyers. The Law on Loan Servicers was enacted in the year. The amount of loans serviced by loan servicers stayed at around 10 trillion yen in 1999 and 2000 but, as a result of the regulator's push to eliminate bad loans from bank balance sheets, jumped to 30 trillion yen in 2001 and stayed at the level till 2010.

- The Resolution and Collection Corporation (RCC): The RCC had purchased bad loans from failed Jusen and banks, but its role was expanded in 2001 so that it can purchase from sound banks as well. The government instructed the RCC to judge if a borrower had a potential for recovery or not, and restructure and revitalize those with potential and rigorously collect from those without. The RCC purchased 3 trillion yen of bad loans from sound banks at the price of 0.3 trillion yen and revitalized around 700 borrowers.

- The Industrial Revitalization Corporation of Japan (IRCJ): A special law to establish the IRCJ was enacted in April 2003 and the Corporation started its business in May, with two years to decide which companies to revitalize and up to five years before exit. The IRCJ resurrected 41 borrowers, whose initial liabilities amounted to 4 trillion yen, or around one quarter of the substandard loans held by 
banks at the time of the IRCJ's start. It made profit amounting to 125 billion yen and, more importantly, released corps of experienced corporate turnaround professionals to the private sector by the time it was disbanded in 2007.

- SME Business Rehabilitation Support Co-operatives: In 2003, based on the revised Law on Special Measures for Industrial Revitalization, SME Business Rehabilitation Support Co-operatives were established in all prefectures. The co-operatives provide advice to small and medium size enterprises (SMEs) and conduct initial discussion with lenders without charging the SMEs. If the SMEs so wish, the co-operatives prepare restructuring plans, coordinate with lenders, and support implementation of the plans. Each year during its early periods, the Co-operatives provided advice to around 3000 SMEs and produced more than 400 restructuring plans.

Procedural improvements were also made.

- In 2000, the Civil Rehabilitation Law was enacted, and an incourt process simpler and more flexible than the process under the Composition Law, which the new law replaced, was introduced. The number of cases of restructuring-oriented court process jumped from 225 in FY 1999 to 769 in FY 2000.

- In 2002, the Corporate Reorganization Act was wholly revamped to make restructuring process for large corporate more efficient, prompt, and effective.

- In addition, the Guidelines for Multi-Creditor Out-of-Court Workout was produced by a group of interested lawyers and representatives of bankers' associations and business associations in 2001 . The guidelines standardized workout steps for troubled companies to be taken in out-of-court processes led by main banks.

The supervisory pressures to make banks remove bad loans from their balance sheet, new players such as loan servicers, the RCC, the IRCJ, and the SME Business Rehabilitation Support Co-operatives, together with the new processes like the Civil Rehabilitation and the Multi-Creditor Out-of-Court Workout, all emerged around the turn of the millennium, worked together to attain simultaneous resolution of bad loan problems and excess debt problems. 


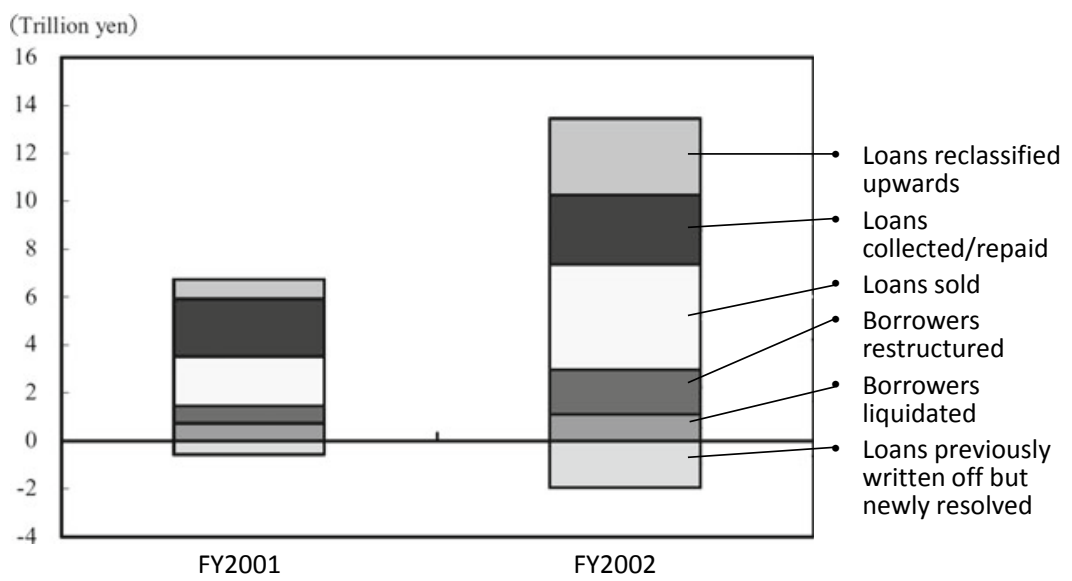

Fig. 6.3 Composition of the loans categorized doubtful or worse and removed from the balance sheets of major banks (Source Cabinet Office [2003], with legend translated by the author)

According to Cabinet Office (2003), the amount of doubtful or worse loans removed from the balance sheets of major banks jumped from 6 trillion yen in FY 2001 to 12 trillion yen in FY 2002 (Fig. 6.3). Of the 12 trillion yen, around 2 trillion yen was the result of the restructuring of the borrowers administered in court. Around 3 trillion yen was resulted from the loans being reclassified upwards, of which $43 \%$ was the outcome of out-of-court restructuring processes. But for the enhancements in actors and processes, many more borrowers might have been simply liquidated.

\section{Labor Market Adjustments}

The Corporate Japan did not resort to massive layoffs during the recessions, and the Japanese labor market never saw such high unemployment rates Europe and the United States saw after the Global Financial Crisis. The Japanese employment system, with some modifications, survived throughout the financial cycle. But the youth and women bore larger share of the adjustment burden than the traditional incumbents of the Japanese lifetime employment system, and the effects persisted even after the recovery of the economy. 
During the in-between years, the unemployment rate steadily rose from around $2 \%$ to around $3.5 \%$. The 1998 crisis pushed it up by one percentage point to around $4.5 \%$, and the wave of corporate liquidation and restructuring in 2001-2002 raised it by another one percentage point to around $5.5 \%$. The unemployment rate then gradually declined to the pre-crisis level of around $3.5 \%$ by mid- 2007 .

Pain was more acute for the younger generation. The unemployment rate among the population aged between 15 and 24, which was at around $4.5 \%$ in the early $1990 \mathrm{~s}$, continued to climb up throughout the $1990 \mathrm{~s}$ and came close to $11 \%$ in the first half of 2002 . The ratio then gradually declined to around $7 \%$ by the first half of 2008 . So-called "job-search ice age," during which new graduates had particular difficulty in finding jobs as lifetime employees, is said to have started in the mid-1990s and have come to an end in the mid-2000s. The cohort which entered the job market during the period, or the "ice-age generation," continued to be disadvantaged. Genda, Kondo, and Ohta (2010) found the negative effects of the unemployment rate at graduation on subsequent employment and earnings are much more persistent in Japan than in the United States.

The core incumbents of the Japanese employment system had their lifetime employment protected, while other groups of employees saw significant deterioration in their job security. Kambayashi and Kato (2017) show that the ten-year job retention rate did not change much for the traditionally priviliged core group of employees, or male regular employees with college degree and at least five-year employment history at the same employer, in spite of the banking crisis and the ensuing corporate restructuring. But the job retention rate for those outside the group significantly declined after 1998.

The seniority-based wage system, where the wage level is a function of the number of years worked at the company, stayed, but the wage for employees in their fifties, a symbol of employers' appreciation of employees' loyalty, was significantly reduced. 
Between 1997 and 2002, the ratio of "regular employees" (those who are expected to have lifetime employment, on-the-job training, and seniority-based wage) in the population changed little for men aged 1870 from 60 to $59 \%$, but for women and the youth (age 22-30), the decline was significant, from 26 to $22 \%$ for women and 61 to $54 \%$ for the youth (Kambayashi and Kato 2016).

The Cabinet Office (2009) found that the growth in the ratio of nonregular employees and the increase in income inequality were particularly pronounced between 1997 and 2002, and that the recovery of income of the lower-income group was much slower than that of the mid- or high-income groups during the economic recovery between 2002 and 2008.

The corporate Japan hired more women, youth, and elderly as nonregular employees with lower costs, and continuously reduced the wage share. This helped the corporate sector accumulate financial surplus at a level equivalent to around 4\% of the GDP almost every year since 1999, as we will see in the next chapter (Fig. 7.1).

\section{How Much Did It Cost?}

The first line of defense against the shocks arising from the asset price collapse is corporate sector's profits and capital. Between FY 1992 and 2004, the non-financial corporate sector recognized 284 trillion yen of non-recurring losses. Corporations incur non-recurring losses even without bubbles, but its sharp rise in the latter half of the 1990s (Fig. 6.4, broken line) suggests that significant part of them should have come from impairments in the values of assets held.

Part of the losses was covered by non-recurring profits (dotted line), including those realized by selling assets with latent gains. The gap between the non-recurring losses and profits, shown by the double line, amounted to 112 trillion yen in total. As non-recurring losses and nonrecurring profits may stay with different companies, however, not all of the latter are available to cover the former. Uncovered non-recurring losses still may be covered by annual ordinary profits and corporations' own capital, but to the extent it could not be covered, banks' claim to the corporations would be impaired, except for the portion compensated by public loan guarantee schemes.

The single line in Fig. 6.4 shows the amount of credit loss recognized by banks. The line, which moved a few years earlier than the double line, 


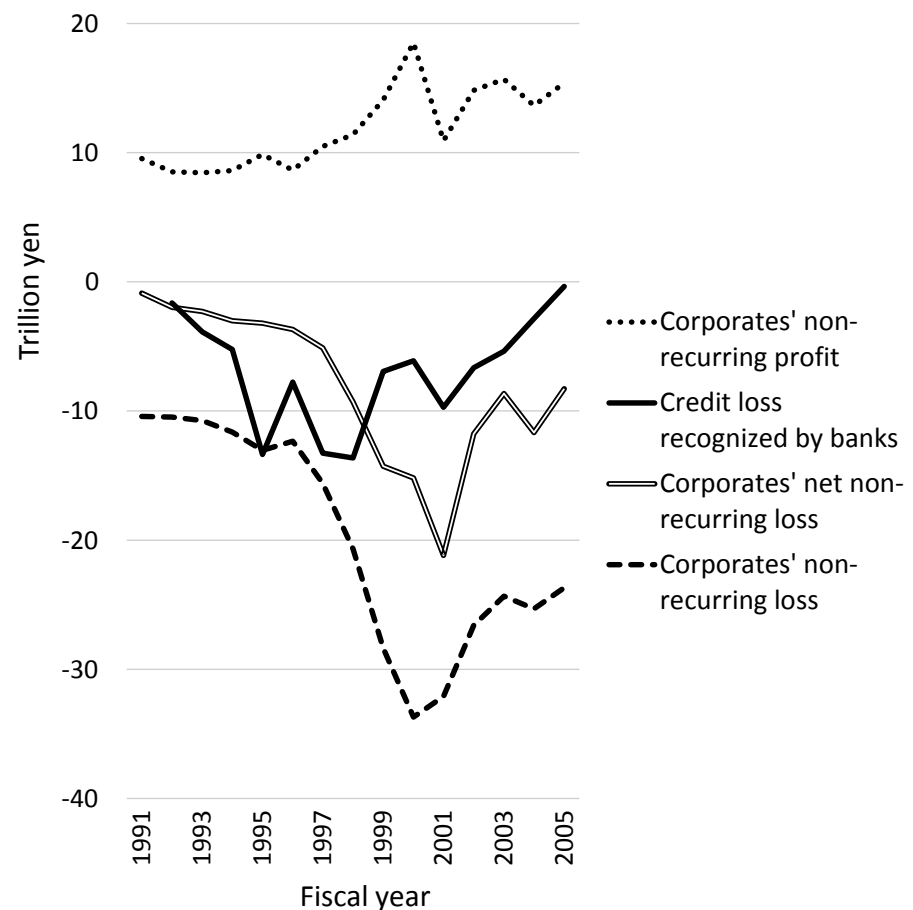

Fig. 6.4 Corporate non-recurring profit/loss and credit cost to banks (Source Ministry of Finance, Financial Statements Statistics of Corporations by Industry; Financial Services Agency, Disclosures according to the Financial Revitalization Act made for the accounting year ending in March 2020 (Reiwa 2 nen 3 gatsu ki ni okeru Kin'yuu Saisei Hou kaiji saiken no joukyou tou), August 2020)

seems to imply that banks provisioned against anticipated losses. Aggregate amount of credit losses reached 96 trillion yen. Banks incur credit losses even during their ordinary course of business, but majority of this extraordinary level of losses may be attributed to the bubbles and their busts. Banks partly covered them by realizing the latent gain in banks' equity portfolio and by annual ordinary profits. To the extent the credit losses could not be covered, banks' own capital was depleted.

The Deposit Insurance Corporation injected 12 trillion yen of capital to undercapitalized banks, which was, in aggregate, recovered with profits. However, it had to pay additional 19 trillion yen to resolve failed 
banks. Part of the resolution cost was recovered by deposit insurance premium, but the residual 10 trillion yen was borne by taxpayers.

Running the risk of oversimplification, it may be said that the collapse of the bubble resulted in capital loss to the corporate sector amounting to $60 \%$ of the annual GDP (284 trillion yen), credit cost to banks amounting to $20 \%$ (96 trillion yen), bank resolution cost to the deposit insurance amounting to $4 \%$ (19 trillion yen), and direct cost to taxpayers amounting to $2 \%$ ( 10 trillion yen). These are the direct financial costs only. Bigger costs accrued to all members of the society in the form of lost revenues due to economic stagnation.

\section{What if the Immediate Clean-Up Option Had Been Chosen in 1992?}

As seen in Chapter 4, the Bank of Japan and Prime Minister Miyazawa in 1992 tried to enhance the public backstop and quickly clean up the problems in the banking system. In the real world, their view did not prevail, but what if the immediate clean-up option had been chosen in 1992?

Given the complexity of the matter, no counterfactual can be reliable even minimally, but it might still be of some interest to try a wild speculation. If we are to assume the consequence of the immediate clean-up could be like a fast-forwarded version of the real history, a counterfactual may look as follows:

Banks continued to deny the problem, and the proposal to introduce a strong public backstop was rejected by the public and the Diet. To demonstrate the need for a backstop, the Ministry of Finance and the Bank of Japan ran special inspections and then disclosed the true magnitude of the problem.

The stock price collapsed as was the case in April 2003. Latent gains on banks' equity portfolios turned to latent losses, and large part of the Japanese banking system was found undercapitalized or insolvent.

Rating agencies downgraded Japanese banks, funding in overseas markets became unavailable, and the Japanese banks, still among the largest in the world, started fire sales of their dollar-denominated assets abroad, turning the global financial markets into turmoil. The US authorities provided a 
friendly advice to their Japanese counterparts that a strong public backstop had to be immediately introduced.

At the same time, as we saw in November 1997, queues were formed in front of bank branches across the country. Blanket deposit protection was declared, and the ruling party decided to introduce public capital injection scheme, as was the case in December 1997. Waves of capital injections, bank resolutions, and the restructuring of borrowers ensued, and bankruptcies, unemployment, and suicide surged as we saw in the wake of the 1998 crisis. Massive public spending was implemented to boost the economy. Responsibilities of relevant bankers and regulators were rigorously pursued.

Would the total costs incurred to non-financial corporations and to banks have been smaller under this scenario? Assuming that the scenario had not resulted in a systemic meltdown with uncontrollable downward spirals, the total cost must have been smaller, as many problems would have been addressed before they exacerbated. Given the size of the problem accumulated over the bubble years, however, the savings might not have been dramatic.

The cost incurred to the non-financial corporate sector was broadly in line with what the sector did during the bubble years. The assets held by the sector grew by 503 trillion yen during the six years between March 1986 and March 1992. The sector bought 123 trillion yen of lands and increased the amount of equities, plant, and equipment on the balance sheets by 141 trillion yen. Compare the sum of the two, 264 trillion yen, with the gross non-recurring losses recognized by the non-financial corporate sector, 284 trillion yen.

Also, the credit cost recognized by banks, 96 trillion yen, may broadly correspond to the size of the problems at the industries which produced bad loans. The real estate industry alone acquired 56 trillion yen of real estate and increased debts to banks by 64 trillion yen during the six years between March 1986 and March 1992 (Fig. 2.3). The construction industry acquired 28 trillion yen of real estates and increased debts to banks by 16 trillion yen. The wholesale and retail distribution industry acquired 57 trillion yen of real estates and increased debts to banks by 32 trillion yen. The three industries alone added to their balance sheets 100 trillion yen of real estates and 112 trillion yen of debts to banks. 
On the other hand, the cost would have been much larger should this scenario have resulted in a systemic meltdown, i.e., if the public confidence in the banking system could not be restituted, bank runs continued, and a downward spiral between the banking sector and the real economy was not halted.

Would the risk of a systemic meltdown have been greater under the counterfactual scenario?

As Fig. 6.4 shows, the non-financial corporate sector recognized the problem largely after the 1998 crisis, and thus an early clean up would have meant doing the same just earlier. On the other hand, in the real life, banks already recognized half of the total credit costs during the inbetween years and had to address only the remaining half after the crisis. If the crisis should be brought forward to 1992, then the banking system would have been required to address much bigger problem at once than was the case in the real life after 1998.

Perhaps more banks would have been resolved in a shorter period, and that might have increased the risk of operational failure in resolution, resulting in a greater risk of a systemic meltdown. Also, only deposit insurance premiums for fewer years could have been counted on. Taxpayers might have had to cover a larger share of the cost. If a national consensus to spend tens of trillions of yen could not have been formed quickly, then the process would have been more prone to a systemic meltdown.

Would the competitiveness of the Japanese industry have been revived more effectively under this alternative scenario?

Most likely so, so far as we assume no systemic meltdown. The problems arising from debt overhang and delayed exit of unviable firms would have been much smaller. The shock could have been deeper and scarier, and the Corporate Japan could have become more risk-averse right after the shock, but a temporary shock would have imposed less damage on entrepreneurship than pains persisting over a decade. The "job-search ice age" generation, who lost the opportunities to benefit from on-the-job training, would have been produced only for much shorter period.

In short, the quick cleaning-up scenario would have had a good upside potential. It may have resulted in smaller (though still large) financial costs for the non-financial corporate sector and for banks, a sharper but shorter bout in unemployment, and better preservation of entrepreneurship in Japan. But it may have resulted in larger costs for taxpayers, and most importantly, could have triggered a systemic meltdown, with possible spillovers to the global financial system. 
Policymakers cannot choose an option on their own unless the risk of triggering an irrecoverable catastrophe is reasonably mitigated. Although a bureaucracy tends to overemphasize the risk, in hindsight there indeed was the risk to see the sum of the two darkest days, November 26, 1997, when depositors' queues were formed across the country, and April 28, 2003 , the day the stock prices hit the lowest point, at once. On the other hand, if there had been a strong public backstop already at the time, the quick cleaning-up option could have reduced the overall social costs while limiting the risk of a systemic meltdown, and the benefit may have outweighed the cost of moral hazard possibly produced by the backstop.

\section{Notes}

1. In July 2000, the Financial System Planning Bureau of the Ministry of Finance and the Financial Supervisory Agency was merged to form the Financial Services Agency. In January 2001, the Financial Reconstruction Commission was merged into the Financial Services Agency.

2. Here, "unviable firms" are defined by unviability of their business models, not by their current financial conditions. The concept is thus unrelated to what Caballero et al. (2008) call "zombie firms." They call a firm zombie if banks' lending terms to it is more favorable than the prevailing market terms, regardless of the viability of its business model. Nakamura and Fukuda (2013) find that a majority of the zombie firms eventually resuscitated during the first half of the 2000s.

\section{REFERENCES}

Aoki, M., \& Patrick, H. (1995). The Japanese main bank system: Its relevance for developing and transforming economies. Oxford: Oxford University Press.

Caballero, R. J., Hoshi, T., \& Kashyap, A. K. (2008). Zombie lending and depressed restructuring in Japan. American Economic Review, 98(5), 1943-1977.

Cabinet Office. (2003). Annual report on the Japanese economy and public Finance 2003-No gains without reforms II.

Cabinet Office. (2009). Annual report on the Japanese economy and public finance 2009-Overcoming financial crisis and vision for sustained recovery.

Genda, Y., Kondo, A., \& Ohta, S. (2010). Long-term effects of a recession at labor market entry in Japan and the United States. Journal of Human Resources, 45(1), 157-196.

Gomi, H. (2012). Financial turmoil, a monologue of an JFSA commissioner (Kin'yuu douran, Kin'yunchou choukan no dokubaku). Nikkei. 
Kambayashi, R., \& Kato, T. (2016). Good jobs and bad jobs in Japan: 1982-2007 (Working Paper Series No. 348). Center on Japanese Economy and Business. Columbia Business School.

Kambayashi, R., \& Kato, T. (2017). Long-term employment and job security over the past 25 years: A comparative study of Japan and the United States. ILR Review, 70(2), 359-394.

Myers, S. C. (1977). Determinants of corporate borrowing. Journal of Financial Economics, 5(2), 147-175.

Nakamura, J., \& Fukuda, S. (2013). What happened to "zombie" firms in Japan?: Reexamination for the lost two decades. Global Journal of Economics, 2(02), 1350007.

Takenaka, H. (2008). The structural reforms of the Koizumi Cabinet: An insider's account of the economic revival of Japan. Tokyo: Nikkei Publishing.

Takemori, S. (2009). Nine faces of economic crises (Keizai kiki ha kokonotsu no kao wo motsu). Nikkei BP.

Open Access This chapter is licensed under the terms of the Creative Commons Attribution-NonCommercial-NoDerivatives 4.0 International License (http:// creativecommons.org/licenses/by-nc-nd/4.0/), which permits any noncommercial use, sharing, distribution and reproduction in any medium or format, as long as you give appropriate credit to the original author(s) and the source, provide a link to the Creative Commons license and indicate if you modified the licensed material. You do not have permission under this license to share adapted material derived from this chapter or parts of it.

The images or other third party material in this chapter are included in the chapter's Creative Commons license, unless indicated otherwise in a credit line to the material. If material is not included in the chapter's Creative Commons license and your intended use is not permitted by statutory regulation or exceeds the permitted use, you will need to obtain permission directly from the copyright holder.

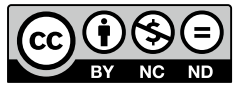

